\title{
Corrigendum: Humanized Mice for the Evaluation of Novel HIV-1 Therapies
}

\section{OPEN ACCESS}

Edited and reviewed by: Qingfeng Chen, Institute of Molecular and Cell Biology (A*STAR), Singapore

*Correspondence: Silke Paust paust@scripps.edu

Specialty section: This article was submitted to Viral Immunology, a section of the journal Frontiers in Immunology

Received: 03 November 2021 Accepted: 08 November 2021 Published: 06 December 2021

Citation:

Abeynaike S and Paust S (2021) Corrigendum: Humanized Mice for the Evaluation of Novel HIV-1 Therapies.

Front. Immunol. 12:808068. doi: 10.3389/fimmu.2021.808068

\section{Shawn Abeynaike ${ }^{1,2}$ and Silke Paust ${ }^{1,2 *}$}

${ }_{1}^{1}$ Department of Immunology and Microbiology, The Scripps Research Institute, La Jolla, CA, United States, 2 The Skaggs Graduate Program in Chemical and Biological Sciences, The Scripps Research Institute, La Jolla, CA, United States

Keywords: humanized mice, BLT, DRAG, HIV-1 infection, viral latency, latency reversal, immunotherapy, gene therapy

\section{A Corrigendum on:}

Humanized Mice for the Evaluation of Novel HIV-1 Therapies

By Abeynaike S and Paust S (2021). Front. Immunol. 12:636775. doi: 10.3389/fimmu.2021.636775

In the original article, there was a mistake in Table 1 as published. The authors incorrectly categorized thy/liv implanted SCID-hu mice as showing no multilineage hematopoeisis. To clarify, Namikawa 1990, showed that SCID mice implanted with both Thy/Liv displayed multilineage hematopoiesis. Specifically, they showed in addition to T cells (CD3, CD4 and CD8), the presence of mature and immature forms of myelomonocytic cells which stained positive for human CD15, as well as progenitors for erythroids and megakaryocytic lineages (1).

The corrected Table 1 appears below.

The authors apologize for this error and state that this does not change the scientific conclusions of the article in any way. The original article has been updated. 
TABLE 1 | Summary of humanized mouse models and their tissue-based chimerism.

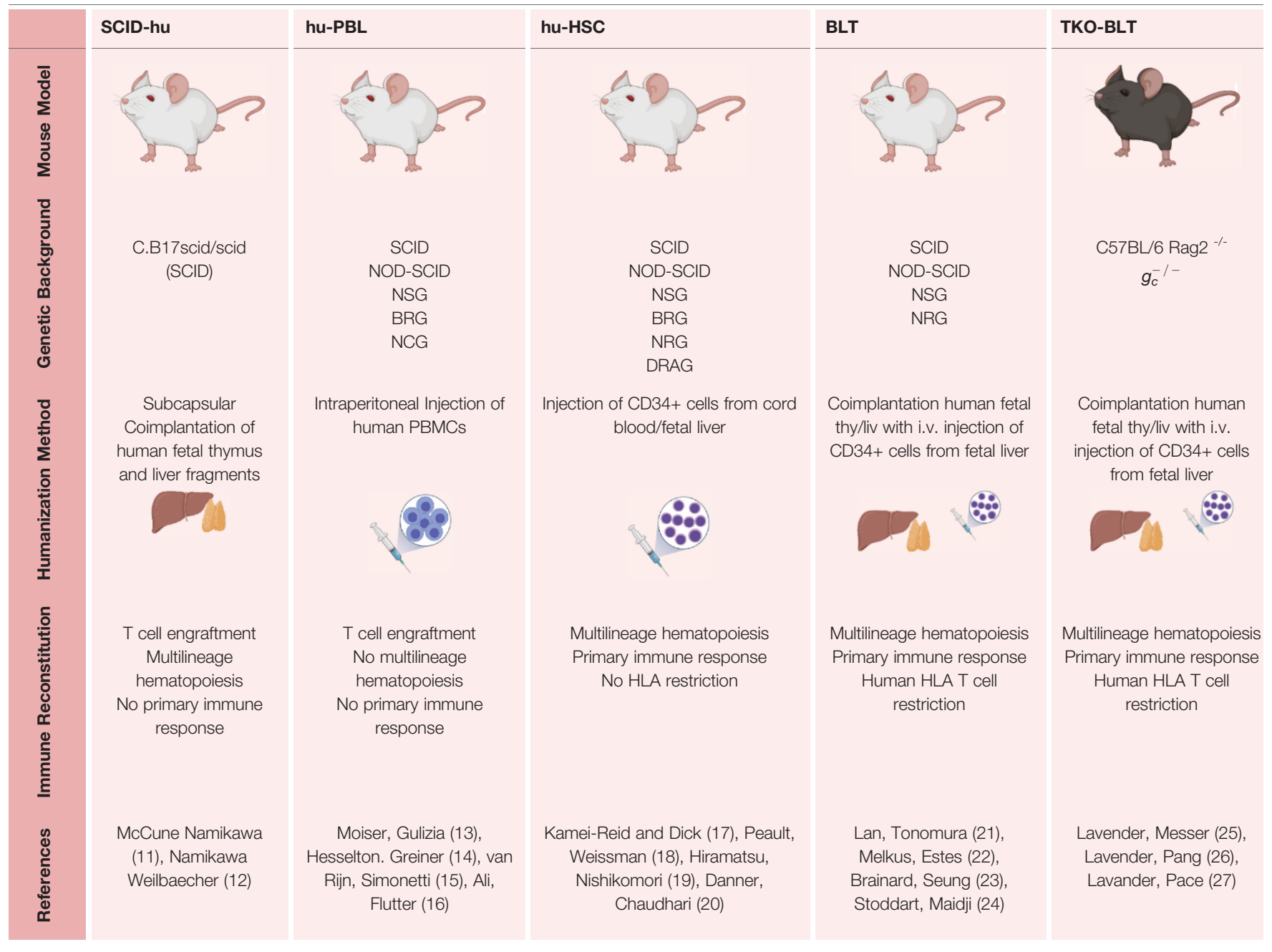

\section{REFERENCE}

1. Namikawa R, Weilbaecher K, Kaneshima H, Yee E, Mccune J. Long-Term Human Hematopoiesis in the SCID-hu Mouse. J Exp Med (1990) 172 (4):1055-63.

Publisher's Note: All claims expressed in this article are solely those of the authors and do not necessarily represent those of their affiliated organizations, or those of the publisher, the editors and the reviewers. Any product that may be evaluated in this article, or claim that may be made by its manufacturer, is not guaranteed or endorsed by the publisher.

Copyright $\odot 2021$ Abeynaike and Paust. This is an open-access article distributed under the terms of the Creative Commons Attribution License (CC BY). The use, distribution or reproduction in other forums is permitted, provided the original author(s) and the copyright owner(s) are credited and that the original publication in this journal is cited, in accordance with accepted academic practice. No use, distribution or reproduction is permitted which does not comply with these terms. 